\title{
Strengthening Islamic Moral (Akhlak) of Orphanage Adolescents Through Group Guidance Activities With Religious Spiritual Cinematherapy Techniques
}

\author{
Arjoni $^{1 *}$, Gusril Basir ${ }^{2}$, Cece Rakhmat ${ }^{3}$ \\ ${ }^{1}$ Universitas Pendidikan Indonesia, Bandung, Indonesia, \\ ${ }^{2}$ IAIN Bukittinggi, Bukittinggi, Indonesia, \\ ${ }^{3}$ Universitas Pendidikan Indonesia, Bandung, Indonesia \\ *Corresponding author. Email: arjonimelamindo@upi.edu
}

\begin{abstract}
This study aims to describe the strengthening of adolescent Islamic morals (akhlak) through group counseling activities with religiously charged Cinematherapy techniques at the Kamang Hilir Orphanage in Kab. Agam. This research uses quantitative with pretest and posttest control group design experimental design. Sampling by purposive sampling. Data collection uses an Islamic morals (akhlak) scale questionnaire. Data were analyzed using the Wilcoxson Signed Ranks Test and Kolmogorov-Smirnov Two Samples. The research results explain; (1) there is a significant difference in the Islamic morals (akhlak) of the pretest and posttest experimental groups, (2) there is no significant difference in the morals of the posttest and posttest control groups, (3) there are significant differences between the morals of the experimental group pretest and posttest control groups. The conclusion of this study states the strengthening of adolescent morals through group counseling activities with religiously spiritual Cinematherapy techniques effective. The results of this study are useful for developing counseling programs to improve Islamic morals (akhlak) of adolescent orphanages.
\end{abstract}

Keywords: Islamic moral (akhlak), cinematherapy, spiritual religious

\section{INTRODUCTION}

Islamic moral (Akhlak) occupies a very important position in human life, someone who has a noble character is seen as a servant who has quality by Allah. A noble person is capable of manifesting positive productive qualities, which includes helping people and sharing good things. According to the words of Allah in QS Shad, 46; "Verily, we did choose them for a special purpose, proclaiming the Message of the Hereafter" (Abudin Nata, 2013). According to the words of Allah in QS Al-Ahzab; 21: "ye have indeed In the Messenger of Allah a beautiful pattern (of conduct) for anyone whose hope is In Allah and the final Day, and who engages much In the Praise of Allah."

Everyone's Akhlak tends to be dynamic, it can be good or bad, and in certain cases tend to be effective or less effective. This is influenced by various factors which are both within and outside the individual. Influence from within is due to lack of knowledge, insight, experiences that should be applied to life (Ali Abdul Halim Mahmud, 2004). And from outside the individual is influenced by the environment which includes mass media, peers and society. These conditions are generally experienced by many people during their adolescence. Adolescents consist generally of individuals within the age range of 13-21 years (Mahmud Yunus, 1978).

Adolescent akhlak are currently experiencing a crisis that affects the task of adolescent development (Abudin Nata, 2008). The more shifting akhlak values, the more negative things will emerge and the impact of adolescent developmental disorders (Rifki Masyur, 2018). Akhlak decline in adolescents can be known through the growing media information that is the number of teenagers who fight, get drunk, gambling, ungodly to parents and even committing murder (Endang Syahrudin, 2012).

Noting the above phenomena, akhlak crisis requires effective intervention, so that the morals of the orphanage children are better. To realize this we need an interesting method and media to strengthen the akhlak of youth through group guidance activities. Achmad Juntika stated; "Group guidance is assistance to individuals carried out in group situations. Group guidance can take the form of 
delivery of information or group activities discussing educational, work, personal and social issues (Achmad Juntika, 2006). The purpose of group guidance specifically encourages the development of feelings, thoughts, perceptions, insights and attitudes that support the realization of more effective behavior, namely the improvement of communication skills both verbal and non verbal (Ramayulis, 2002). Strengthening adolescent akhlak through group guidance can be developed using various media and techniques including Cinematherapy techniques. Cinematherapy techniques is a method of brief assistance, dynamic training because it facilitates quickly between personal and therapeutic understanding between counselor and counselee. Dermer and Hutchings define the Cinematherapy techniques of using film as an intervention and describe it as an indirect approach process, which can be applied to deal with various problems (Berg-Cross, L., Jennings, P., \& Baruch, R, 1990; Dermer, SB, \& Hutchings, JB 2000,). The problems referred to in this case include the issue of teenage akhlak degradation. Sorina Daniela Dumtrache (2014) explained in her research results the Cinematherapy techniques intervention by using film as support in the process of personal development, in modeling the emotional dimensions, values and behavior of the human personality. Michael Lee Powell \& Rebecca A. Newgent (2010) revealed the results of research showing that statistically and clinically effective structured and non-directive group cinema therapy interventions can reduce hopelessness. The selection of cinema films to be presented in cinematherapy interventions requires carefulness and adjustments to individual development (Emily Marsick, 2010).

The selection of films that provide positive content for the akhlak development of the orphanage among them is a film that has spiritual diversity. Ross and Oscar Kupky in Jalaluddin Rahmat revealed the results of their research namely; adolescents experience conflict and doubt about the teachings of the religion they receive. Experiencing symptoms like this, religion has a strategic role in overcoming adolescent inner turmoil. Religious teachings provide clues to display the values of goodness. It is hoped that young people will see that religion is not just a ritual, but religion can protect and care for them (Jamil Shaliba, 1978). The development of religious spiritual power in adolescence is caused by several factors, including the growth of thought and mentality, the development of feelings, social considerations, moral development, attitudes and interests and worship as revealed by W. Starbuck in (Jamil Shaliba, 1978).

Fazlur Rahman said that the core teachings of Islam as contained in the Koran are morals that rely on faith in
Allah (hablu min Allah), and social justice (hablu min annas) .5 Therefore, therefore, the position of morals in human life occupies very important things, both as individuals and as members of society and nation, because of the ups and downs, glorious destruction, prosperity or destruction of a nation and society, depending on how the character.

From the background explanation above, thus this study aims to reveal whether the strengthening of the orphanage adolescents' morality through religious spiritual Cinematherapy group guidance services can be strengthened?

\section{METHOD}

This type of experimental research is carried out with a pre-test and post-test control group design. The experimental group was given counseling service with cinematherapy technique while the control group was given group counseling services without a maternity cinematherapy technique. The study population was adolescents who lived in the Aisyiyah Kamang Hilir Orphanage, Agam District. The sampling was done using the following considerations; The subjects of the research were only teenagers who have weak akhlak, and the subjects of the experiment and control groups were not more than 15 people, this is supported by Prayitno who stated that the number of members in group counseling activities should be between 5 and 15 people to make the discussions broader and deeper (Nikmarijal, 2012).

Based on these considerations, the number of subjects in this study was 20 people, which were divided into 10 experimental and 10 control groups. The implementation of the experiment was carried out with the guidance service of the cinemateraphy group, and it was carried out in seven meetings. The instrument of this research is the questionnaire of religious spiritual power specifically on the moral aspect with skla likert. Before the questionnaire was used, a validity test was used. Of the 65 items, there are 45 items that are declared valid while the reliability test results with Cronbach alpha of 0.947 .

The research data is in the form of religious spiritual power variables on akhlak aspects, with the following characteristics: (a) pairing (pre-test-post-test), (b) small samples (research subjects amounting to 20 people), (c) the distribution of data is not normal, (e) using experimental/ treatment research. Based on these characteristics, the data analysis technique method used is non-parametric.

After the data was collected through pre-test and post-test, then analyzed using the Wilcoxson Signed 
Ranks Test and Kolmogorov-Smirnov Two Samples, with the help of SPSS version 22.

\section{RESULTS AND DISCUSSION}

To find out the results of this study, researchers conducted data testing using a non-parametric test, using the Wilcoxon Signed Rank formula assisted by SPSS version 22. The results of testing the hypothesis are explained as follows;

1. There is a significant difference between the adolescent akhlak of the pretest and posttest experimental groups posttest.

From the results of data processing, the differences between the pre-test and post-test adolescent akhlak of the experimental group were obtained, and the calculation results can be seen in the following table:

Table 1. Wilcoxon analysis results signed ranks test differences in the akhlak of adolescents in the pretest and post-test experimental group

\begin{tabular}{llll}
\hline & \multicolumn{3}{c}{ Test Statistics } \\
\hline & $\mathrm{Z}$ & $\begin{array}{l}\mathrm{Z} \\
\text { hitung }\end{array}$ & $\begin{array}{l}\text { Asymp.Sig.(2- } \\
\text { tailed) }\end{array}$ \\
\hline Pretest & 2.809 & 3.7664 & .005 \\
- & & \\
Posttest & & & \\
\hline \multicolumn{3}{l}{ Source: Arjoni research analysis results }
\end{tabular}

Based on the data in table 1, it can be understood that the probability number of the Asmyp. Sig. (2-tailed) adolescent akhlak in the experimental group is at 0.005 or has a probability below alpha $(0.005<0.05)$. Thus, it can be understood that the hypothesis tested in this study is acceptable. That is, "There are significant differences in adolescent akhlak in the experimental group before and after being treated by the cinemateraphy group counseling service". Henceforth, it is necessary to know about the direction of the difference between the pre-test or posttest in the table below:

Table 2: Differential Directions for the Pretest and Posttest of Adolescent Akhlak in the Experimental Group

\begin{tabular}{|c|c|c|c|c|}
\hline \multicolumn{5}{|c|}{ Ranks } \\
\hline & & $\mathrm{N}$ & $\begin{array}{l}\text { Mean } \\
\text { Rank }\end{array}$ & $\begin{array}{l}\text { Sum of } \\
\text { Ranks }\end{array}$ \\
\hline \multirow{3}{*}{$\begin{array}{l}\text { Postest- } \\
\text { Pretest }\end{array}$} & Negative Ranks & $0^{\mathrm{a}}$ & .00 & .00 \\
\hline & Positive Ranks & $10^{\mathrm{b}}$ & 5.50 & 55.00 \\
\hline & Ties & $0^{c}$ & & \\
\hline
\end{tabular}

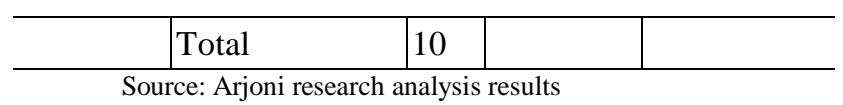

Based on the data in table 2, it can be understood that from 10 people in the experimental group, all of them experienced a moral reinforcement of the results of the pretest to posttest. It can also be interpreted that the experimental group experienced a strengthening of morals after the intervention of group guidance activities with religious spiritual cenemateraphi techniques. The results of this study reinforce the opinion of Hamzah Ya'ubub (1993) suggesting the factors that influence the formation of morals are principally influenced and determined by two main factors namely internal and external factors namely; habits, descent, will and desire, conscience, environment, family, education (Hamzah Ya'qub 1993). The results of this study reinforce the research results of Ana Filipa Correia (2018) the film seems to help clarify the treatment pathway and metaphorically help connect patients with the therapeutic process. Furthermore, the results of this study are in line with the results of Mary B. Ballard's research (2012) suggesting that cinematherapy techniques can develop understanding and improve communication so that they can develop community morals (Mary B. Ballard (2012).

2. There was no significant difference between the adolescent akhlak of the pretest and posttest control group.

From the results of data processing differences between adolescent akhlak of the pre-test and that of the post-test in the control group obtained, the calculation results can be seen in the following table:

Table 3. Wilcoxon analysis results signed ranks test differences in the akhlak of the orphanage in the control group pretest and posttest

\begin{tabular}{llll} 
& Z & Z hitung & $\begin{array}{l}\text { Asymp.Sig.(2- } \\
\text { tailed) }\end{array}$ \\
\hline $\begin{array}{l}\text { Pretest } \\
\text { Posttest }\end{array}$ & -1.826 & 2.6613 & .068 \\
\hline \multicolumn{3}{r}{ Source: Arjoni research analysis results dkk }
\end{tabular}

Based on the data in table 3, it can be understood that the probability number of the Asmyp. Sig. (2-tailed) experimental group adolescent akhlak is 0.068 or probability above alpha $(0.068<0.05)$. So it can be understood that the hypothesis tested in this study was accepted, and it shows that "There was no significant difference in adolescent akhlak in the control group 
before and after receiving the group counseling service of the cinematherapy ":

Table 4: Differential direction of pretest and Posttest for Adolescent akhlak in the experimental group

\begin{tabular}{lllll}
\hline \multicolumn{5}{c}{ Ranks } \\
\hline & \multicolumn{3}{c}{$\begin{array}{l}\text { Mean } \\
\text { Rank }\end{array}$} & Sum of Ranks \\
\hline $\begin{array}{l}\text { Postest- } \\
\text { Pretest }\end{array}$ & $\begin{array}{l}\text { Negative } \\
\text { Ranks }\end{array}$ & $0^{\mathrm{a}}$ & .00 & .00 \\
\cline { 2 - 5 } & $\begin{array}{l}\text { Positive } \\
\text { Ranks }\end{array}$ & $4^{\mathrm{b}}$ & 2.50 & 10.00 \\
\cline { 2 - 5 } & Ties & $6^{\mathrm{c}}$ & & \\
\cline { 2 - 5 } & Total & 10 & & \\
\hline
\end{tabular}

Source: Arjoni research analysis results dkk

Based on the data in table 4 , it shows the value $4^{b}$. This means that of the 10 teenagers in the control group, only a few teenagers experienced moral reinforcement from pretest to posttest. The data section, it also shows that the mean pretest and posttest also experience strengthening. But the reinforcement was proven insignificant between pretest and posttest in the control group. In addition, it can also be seen that the distribution of figures obtained is not evenly distributed, ie there are those that experience reinforcement and some that do not experience reinforcement.

From the results of these studies indicate that akhlak strengthening can be done through group guidance activities even without the application of Cinematherapy techniques, but the expected results have not shown optimal results. Achmad Juntika stated; "Group guidance is an activity of assistance to individuals carried out in group situations. Group guidance can take the form of delivery of information or group activities discussing educational, work, personal and social issues "(Achmad Juntika, 2006). Prayinto stated; "Group guidance is carried out to enable group dynamics aimed specifically at discussing specific topics that contain actual (warm) problems and are of concern to group participants, thus encouraging the development of feelings, thoughts, perceptions, insights, attitudes that support the realization of more effective and effective behavior. responsible (Prayitno, 2012).

3. There is a significant difference between adolescent akhlak in the experimental group and the pre-test and post-test control group.
From the results of data processing, the differences between adolescent akhlak in the experimental group and the pre-test and post-test control group are as follows:

Table 5; Wilcoxon Analysis Results Signed Ranks Test Differences in the akhlak of adolescent orphanage in the experimental group with the pretest and post-test control group.

\begin{tabular}{llc}
\hline \multicolumn{2}{c}{ Test Statistics $^{\mathbf{a}}$} \\
\hline Most Extreme Differences & & Posttest \\
\cline { 2 - 3 } & Absolute & 1.000 \\
\cline { 2 - 3 } & Positive & .000 \\
\cline { 2 - 3 } & Negative & -1.000 \\
\hline Kolmogorov-Smirnov Z & & 2.236 \\
\hline Asymp. Sig. (2-tailed) & .000 \\
\hline t Tabel & .409 \\
\hline
\end{tabular}

Based on the data in table 5 above, you can know that akhlak in the Asymp column Sig. (2-tailed)/ significances for two-sided tests are 0,000 with other forms $(0,0005$ $0,05)$ or $\mathrm{t}$ count $<\mathrm{t}$ table $(0,000<0,409)$, then $\mathrm{Hi}$ is rejected and Ho is accepted. It can be seen that there are significant differences in adolescent akhlak in the experimental group and the control group.

Based on the results of the posttest in the experimental group that was given the treatment of Cenemateraphi technique group guidance services obtained changes. The results of data processing of adolescent akhlak which were originally in the category are not good, increased to be in the medium category, good even some of the adolescent akhlak increased very good category.

While in the control group carried out group guidance activities without Cenemateraphi content, there were also changes. The results of the moral deception data of adolescents in the control group that were originally dominated were in the unfavorable category, some of the adolescents increased to be in the moderate category, but from the results of the adolescent akhlak posts which were in the poor, good, and very good category

From the results of this study explain, Cenemateraphi technical group guidance activities can improve the akhlak of adolescent foster care. This explains the methods and media to improve akhlak that are influenced by factors within and outside the self can be done through the action of the Cenemateraphi technique group guidance services

Cinematherapy is the best short-term assistance technique, the training is dynamic because it facilitates 
quickly the personal and therapeutic understanding between counselors and counselees (Berg-Cross, L., Jennings, P., \& Baruch, R. 1990). This action has been applied in terms of increasing the akhlak of orphanage adolescents in the Aisyiah Kamang Hilir. Applying cinematherapy to group counseling services became attractive to counselees, Dermer et al explained the use of film as an intervention and described it as an indirect approach, which could be applied to deal with some problems experienced by adolescents (Dermer, S.B., \& Hutchings, J.B,. 2000; Marsick, Emily, 2000, Mary B. Ballard, 2012). Broadcasts on this activity are jembatan pensil films, lascar pelangi films, the sang pencerah films and denias films, as well as the application statements from Tyson, Foster, and Jones saying: "Cinematherapy shows a therapeutic approach that prepares clients to watch and assess the film based on their interaction with others, their environment, and personal problems, by developing links to complete positive therapeutics (Tyson,Foster, dan Jones, 2000).

There are content and characters in this film adapted to the knowledge, socio-emotional of the orphanage teenagers. This character or film portrays a figure who has good character (Rosihon, 2010). Morals are behaviors that show someone's faith and faith in the well-being he believes in (Abudin Nata, 2013; Ali Abdul Halim Mahmud, 2004). The behavior in daily life according to Anwar Rosihon consists of several things, namely; Convincing God, morals towards oneself, morals with family, morals with society, morals with the environment (Ali Abdul Halim Mahmud, 2004).

The power behind cinematology lies in the metaphors inherent in every film. Metaphors are words or symbols that are applied to objects or concepts to show a comparison between two things. In films, characters and themes are potential metaphors (Sharp, C, Smith, J.V., \& Cole, A. 2002). Based on the above explanation, it can answer the hypothesis of akhlak reinforcement through group guidance activities with effective religious-spiritual Cenemateraphi techniques.

\section{CONCLUSIONS}

The results of this research study can be summarized as There is a significant difference between the adolescent akhlak of the pre-test and that of the post-test experimental groups, There was no significant difference between adolescent akhlak in the pre-test and that of the post-test control group, and There is a significant difference between adolescent akhlak in the experimental group and pre-test and post-test control group.

Based on the findings above, it can be concluded that strengthening spiritual religion in the moral aspects of adolescents through the cenemateraphy group counseling activities increases.

\section{REFERENCES}

Ana Filipa Correia, Doutor Fernando, 2014. Cinema, aesthetics, and narrative: Cinema as therapy in substance use disorders, The Arts in Psychotherapy; Volume 60, September 2018, Pages 63-71, https://doi.org/10.1016/j.aip.2018.07.001

Abudin Nata, Manajemen Pendidikan Mengatasi Kelemahan Pendidikan Islam di Indonesia, (Jakarta: Kencana, 2008)

Abudin Nata, 2013. Akhlak Tasawuf dan Karakter Mulia, Jakarta: PT.Raja Grafindo Persada.

Achmad Juntika, 2006. Bimbingan dan Konseling dalam Berbagai Latar Kehidupan, Bandung: PT Refika Aditama.

Ali Abdul Halim Mahmud, 2004. Akhlak Mulia, Jakarta: Gema Insani.

Arjoni, 2016. Kontribusi Kekuatan Spiritual Keagamaan terhadap Hasil Belajar Siswa SMK Sumatera Barat (Proceeding Bukittinggi Conseling Conference), Bukittinggi: LP2M IAIN Bukittinggi.

Asmaran, 1992. Pengantar Studi Akhlak, Jakarta: Rajawali Press.

Berg-Cross, L., Jennings, P., \& Baruch, R. 1990. Cinematherapy: Theory and Application. Psychotherapy in Private Practice 8 (1), 135-156.

Dermer, S.B., \& Hutchings, J.B. 2000. “Utilizing Movies In Family Therapy: Applications for Individuals, Couples, and Families". American Journal of Family Therapy. 28, 163-180.

Dewa Ketut Sukardi, 2003. Manajemen Bimbingan dan Konseling di Sekolah, Bandung: Alfabeta.

Endang Syahrudin, 2012. Efektivitas Pembinaan Pendidikan Akhlak Pada Anak Asuh di Panti Asuhan Al Jamiyatul Wasliyah Kota Binjai, Thesis Program Pascasarjana UIN Syarif Hidayatullah

Hamzah Ya"qub 1993, Etika Islam, Bandung: Diponegoro

Hesley, J.W. \& Hesley, J. G. 2001. Rent Two Films and Let's Talk in the Morning: Using Popular Movies in Psychotherapy (2nd ) NY: Wiley and Sons.

Imam Abdul Mukmin Saadudin, 2006. Meneladani Akhlak Nabi, Bandung: Reamaja Rosda Karya.

Jalaludin, 2003. Psikologi Agama, Jakarta: PT. Grafindo Persada. 
Jamil Shaliba, 1978. Al-Mujam Al-Falsafi, Juz I, Mesir; Dar Al-Kitab Al Mishri

Khalimi, 2006. Berkidah Benar Berakhlak Mulia Yogyakarta: Pustaka Insan Madan.

M.Ali, 2004. Psikologi Remaja, Perkembangan Peserta Didik, Jakarta: PT.Bumi Aksara.

Mahmud Yunus, 1978. Pokok-Pokok Pendidikan dan Pengajaran, Jakarta: Agung.

Mahmud Toher, Kajian Islam Tentang Akhlak dan Karakteristiknya (Jurnal UNISBA Volume XXIII No.1) Bandung, [Internet]. 2007, Available from: https://ejournal.unisba.ac.id/index.php/mimbar/art icle/view/23

Marsick, Emily, 2000."Film Selection in a Cinematherapy Intervention With Preadolescent Experiencing Parenta IDivorce". Journal of Creativityin Mental Healt (5) : 374-388.

Marzuki, 2009. Prinsip Dasar Akhlak Mulia, Yogyakarta, Debut, Wahana Press

Mary B. Ballard, 2012. Keluarga Life Cycle dan Kritis Transisi: Memanfaatkan Cinematherapy untuk Memfasilitasi Memahami dan Meningkatkan Komunikasi, Journal of Creativity in Mental Health, Volume 7, 2012 - Issue 2, https://doi.org/10.1080/15401383.2012.685004

Munbjib Abdullah, 1998. Fitrah dan Kepribadian Sebuah Pendekatan Psikologis, Tesis (tidak diterbitkan), Padang: Pascasarjana IAIN Imam Bonjol Padang.

Nikmarijal, 2012. Peningkatan Self-Esteem Dengan Layanan Informasi Bermuatan Cinematherapy; Tesis (Tidak diterbitkan), Padang, UNP

Prayitno, 2012. Jenis Layanan dan Kegiatan Pendukung Konseling, Padang, UNP Press 20-21

Ramayulis, 2002. Pengantar Psikologi Agama, Jakarta: Kalammuliya

Rosihon, 2010. Akhlak Tasawuf, Bandung: Pustaka Setia, 89-92

Rifki Masyur, 2018. Kinerja Pengasuh dalam Pembinaan Akhlak Anak di Panti Asuhan Yatim Piatu Kinderhut Indonesia, DAYAH: Journal of Islamic Education Vol. 1, No. 2, 2018, 205-222

Save M.Dangun, 1990. Psikologi keluarga, Jakarta, Rineka Cipta

Sharp, C, Smith, J.V., \& Cole, A. 2002. "Cinematherapy: Metaphorically Promoting Therapeutic Change". Counselling Psychology Quarterly, 271-272

Sorina Daniela Dumtrache, 2014. The Effects of a Cinema-therapy Group on Diminishing Anxiety in Young People, Procedia - Social and Behavioral Sciences Volume 127, 22 April 2014, Pages 717721, https://doi.org/10.1016/j.sbspro.2014.03.342
Tyson, L. E., Foster, L. H., \& Jones, C. M, 2000.“The Process of Cinematherapy as a Therapeutic Intervention". Alabama Counseling Association Journal, V 26, 35-36.

Wolz, Birgit. 2005. E-Motion Picture Magic CO: Glenbridge Publishing Ltd.

Zwick, Joel. (Driector). (2002): (Driector). My Big Fat Greek Wedding. (Motion Pictures). United States. Hal 137

Yahya Jaya, 2011, Konseling Kekuatan Spiritual Keagamaan dan Ketuhanan, Konsepsi Lugmanu Hakim Tentang Pelayanan Khusus Pendidikan Agama Islam, Padang; Pusat Penelitian IAIN Imam Bonjol Padang.

Yunahar Ilyas, 2004. Kuliah Akhlaq, (Yogyakarta : Lembaga Pengkajian dan Pengamalan Islam/LPPI 